\title{
Ciberespaço em pandemia: eficácia das "lives" espiritualistas na saúde mental
}

\author{
Pandemic cyber space: effectiveness of spiritualist lives on mental health
}

\section{Márden Hott ${ }^{1}$}

\section{RESUMO}

O espiritismo à brasileira se notabilizou pelo poder discursivo nas palestras, contudo, no cenário de isolamento social, requerido pelo contexto do Novo Coronavírus, esta prática presencial foi cerceada objetivando conter a proliferação viral através do contágio interpessoal ou via fômites. Os conferencistas espíritas ganharam considerável amplitude no ciberespaço, promovendo uma verdadeira pandemia de live's ou transmissões ao vivo, empenhados em manter a sanidade emocional mediante o alicerce da espiritualidade, considerando que um grande número de pessoas estão sendo impactadas negativamente na saúde mental se comparadas aos infectados pelo microrganismo em evidência. Os esforços cibernéticos têm atraído inúmeros espectadores, o que demonstra a eficiência das iniciativas dos "educadores", mas nem sempre sua eficácia. Quando se trata da relação entre redes sociais e espiritualidade é substancial observar a importância da emissão dos temas para os públicos, buscando perceber se a informação está adaptada ao propósito, contemplando as expectativas dos envolvidos. As live's sobre espiritualidade são combustíveis para enfrentamento das fragilidades emocionais do momento global, porém precisam ser otimizadas, as pautas necessitam da diversidade, os horários carecem de alternativas e requerem atenção ao espectador, assim servirão como verdadeira fonte de cuidado para com as dimensões humanas.

Palavras-chave: Coronavírus; Pandemia; Saúde Mental; Espiritualidade; Redes Sociais.

\section{ABSTRACT}

Brazilian spiritism was notable for its discursive power in the lectures, however, in the scenario of social isolation, required by the context of COVID-19, this face-to-face practice was curtailed in order to contain viral proliferation through interpersonal contagion or via fomites. Spiritist lecturers have gained considerable breadth in cyberspace, promoting a true pandemic of lives, committed to maintaining emotional sanity through the foundation of spirituality, considering that a large number of people are being negatively impacted on mental health compared to those infected. by the microorganism in evidence. Cyber efforts have attracted countless viewers, which demonstrates the efficiency of "educator" initiatives, but not always their effectiveness. When it comes to the relationship between social networks and spirituality, it is substantial to observe the importance of issuing themes to audiences, trying to understand if the information is adapted to the purpose, considering the expectations of those involved. The lives on spirituality are fuel to face the emotional weaknesses of the global moment, but they need to be optimized, the guidelines need diversity, the schedules lack alternatives and require attention to the viewer, thus they will serve as a true source of care for human dimensions.

Keywords: Coronavirus; Pandemic; Mental Health; Spirituality; Social Networks.

Como citar este artigo / How to cite this article

Hott M. Ciberespaço em pandemia: eficácia das "lives" espiritualistas na saúde mental Pandemic cyber space: effectiveness of spiritualist lives on mental health InterAm J Med Health 2020;3:e202003036. 


\section{CONSIDERAÇõES INICIAIS}

"Educar e educar-se, na prática da liberdade, não é estender algo desde a "sede do saber", até a "sede da ignorância" para "salvar", com este saber, os que habitam ignorância" para "salvar", com este saber, os que habitam liberdade é tarefa daqueles que sabem que pouco sabem - por isto sabem que sabem algo e podem assim chegar a saber mais - em diálogo com aqueles que, quase sempre, pensam que nada sabem, para que estes, transformando seu pensar que nada sabem em saber que pouco sabem possam igualmente saber mais." [1]

O espiritismo à brasileira se notabilizou pelo poder discursivo, tendo no seu modo de culto - apesar de não ser entendido pelos adeptos como tal - as palestras espíritas. Estas se proliferaram nas Casas Espíritas, em ginásios ou auditórios, por meio da serventia do conteúdo e, em alguns casos, pela moeda de troca, agregando capital a causa ou diretamente ao expositor. A proporcionalidade de audiência é dada à eloquência de quem as profere, bem como àqueles mais "festejados", os ilustres conferencistas. Contudo, no cenário da Síndrome Respiratória Aguda Grave (SARS-CoV-2) esta prática presencial foi cerceada ao menos parcialmente - em função do necessário isolamento social que tenta conter a proliferação viral através do contágio interpessoal ou via fômites.

Assim, uma maneira já existente de interação entre "doutrinadores e doutrinados", mas até então discretamente difundida, ganhou considerável amplitude: discretamente difundic "pandemia" em função do número explosivo de live's - ou transmissões ao vivo. Em um mundo ascendente de casos do Corona Virus Disease 19 (COVID-19) tecnologia se tornou o recurso mais utilizável e viável para toda e qualquer situação, dentre elas o empenho em manter a sanidade emocional mediante o alicerce da espiritualidade. Vale salientar que grande é o número de pessoas estão sendo impactadas negativamente na saúde mental se comparadas aos infectados pelo microrganismo em evidência [2].

Os esforços cibernéticos têm atraído inúmeros espectadores, o que demonstra a eficiência das iniciativas dos "educadores", mas nem sempre sua eficácia. Ao considerar que as mensagens são ecoadas por determinadas fontes de maneira unilateral que, embora sejam notadamente de cunho otimista, possuam conteúdos (em muitos casos) pré-estabelecidos, tornando os destinatários meros observadores. Portanto, a problemática está na ausência de integração e interação entre emissores e receptores. A transmissão que é verticalizada parte do pressuposto de que há uma superioridade de quem entende e escolhe o que e como transmitir, desconhecendo a visão de mundo dos que vão receber: abandonando os mesmos à passividade no processo [3].

Nas transmissões que abordam a espiritualidade é preciso entender que quando os temas e os interlocutores estão bem integrados, haverá uma contribuição de forma positiva para a saúde mental, mas para tanto é preciso examinar a forma como o ser se deixa influenciar, como interpreta essas experiências e o que ela produz enquanto sentido para a sua vida [4]. Estudos evidenciam que as redes sociais elevam a probabilidade de manter a saúde mental em todo o contexto de algum tipo de evento traumático ou crise [5]. Logo, nos espaços proporcionados pelas mídias digitais e sua inserção no âmbito do cuidado em saúde, o diálogo é intensificado, o tempo é otimizado, o deslocamento subjetivo (e não meramente geográfico) eromovido enquanto saberes, poderes e afetos circulam

\section{QUAL A "LIVE" DE HOJE?}

A web - palavra inglesa que significa rede ou teia persuade de forma multifacetada a vida contemporânea, pois o virtual e o real se integram progressivamente e criam conjunturas para aquinhoar saberes e práticas [7]. Generalizando, esta estrutura pode ser definida como uma disposição de pessoas ou organizações interligadas por convívio horizontal e não hierárquico, no qual ambiente de ampla sociabilidade. O referido ciberespaço deve ter como premissa o encargo de aprimorar e transacionar a cultura a partir do permanente crescimento e diversidade, considerando que é possível perceber que a cada momento é instituído um arsenal de novas fontes de contatos ofertados por distintas plataformas digitais [9]

Contudo, são vários os fatores que interferem na elaboração deste sistema de comunicação, o que requer categórico entendimento a respeito do interagir com as pessoas, do planejar o processo e do criar argumentos específicos para cada audiência, pois só há comunicação quando há transmissão e recepção de mensagens, seguidas de resultados [10]. Todavia, a internet transpõe a tecnologia que permite 0 acesso à informação onde os participantes não podem ser considerados meros usuários, pois estes usuários são na verdade seres sociais que (re)constroem intersubjetividades no processo de "navegação" [11].
$\mathrm{Na}$ atualidade, quando se trata da relação entre redes sociais e espiritualidade/religiosidade é substancial observar a importância da emissão dos temas para os públicos, buscando perceber se a informação está adaptada ao propósito, contemplando as expectativas dos envolvidos [9]. Nesses temos, o pretenso objetivo a ser alcançado: a prevenção ou promoção da saúde mental/emocional, se não for bem trabalhado, será tentativa frustrada que poderá acarretar efeito reverso. Portanto, as pessoas necessitam de estímulos com assuntos personalizadas e atuais, elevando o impacto e a abrangência da ideia emitida para atingir aqueles que têm interesse em determinado tipo de conhecimento [12]; buscam nessas fontes o apoio para preservação da saúde mental, uma vez que já se percebem com abalos neste mental,

A pergunta dos internautas que não quer calar é "qual a live de hoje?". Para o grupo que se sente emocionalmente afetado pelos transtornos ocasionados pelo COVID-19, o inquérito não é apenas para se inteirarem do motivo, sob a ótica espiritualistar que culminou dom una virose pandemica que esta provc culminou em uma virose pandermica que está provocando tantas mortes que somadas sáo caracterizadas como "desencarnes coletivos". Para esta questão as repostas chegam das mais variadas maneiras, a maioria sustentada pela referência da Codificação Kardequiana - que originou a Doutrina Espírita - registrada em livros desde o final do século XIX e para mais, agregam suas próprias teorias baseadas neste viés.

Saber a causa da epidemia já se tornou lugar comum, as respostas geralmente possuem o mesmo teor do ponto de vista espiritual e já foi entendido que é preciso ir além por meio da ciência experimental, pois são os pesquisadores que estão envolvidos em trazer soluções aplicáveis materialmente, como tratamentos de saúde e formas de imunização. Enquanto as respostas objetivas não chegam, a humanidade quer saber como lidar com as consequências da pandemia em suas questões emocionais recheadas de dilemas no hoje e para o amanhã.

Neste cenário, os oradores espíritas, especialmente aqueles de maior notoriedade, saíram dos espaços físicos, onde o contato com alguns já era restrito (tendo em vista a posição de celebridades) e se inseriram eclosivamente nas redes sociais, respaldados pelo princípio de que a maior caridade que se pode fazer para a doutrina "consoladora" é divulgá-la. Portanto, para que isso se concretize é preciso estudar Allan Kardec - o codificado -, sob a luz da mensagem Cristã, sendo protótipo postura e rememorando que o Espiritismo requer em seu jaez a benignidade da sua difusão" [13].

Porém, é comum durante a realização deste tipo de live as pessoas interagirem umas com as outras sobre assuntos que não estão diretamente relacionados com o tema proposto pelo enunciador, mesmo assim, estas percebem neste círculo um canal para sanar suas dúvidas, caso contrário, não estariam presentes virtualmente. De forma espontânea, neste mesmo espaço, os internautas, percebendo a angústia de seus pares em terem seus nquéritos sanados, se mobilizam em um processo cooperativo e buscam apoiar aqueles que manifestaram suas demandas respondendo - eles mesmos - aos questionamentos dos parceiros de jornada expectante.

Posto isto, as pessoas inseridas no ciberespaço, por necessidade individual ou coletiva, estão sendo amparadas pelo grupo de conversação, muitas vezes não se atentando ao foco da discussão que o emissor determinou. Excluindo os aplausos manifestos, considerando que existem live's de alta qualidade, há outro lado a ser percebido, pois este ambiente tem se tornado um meio de interação muito maior de espectador para espectador, do que dos palestrantes para com estes. Outra questão relevante é que as transmissões trazem visitantes para exporem suas expertises, estas são enunciadas em determinados formatos (como perguntas e respostas) e acabam por serem veiculadas em descompasso com a proposta, visto haver também a falta de interação e integração entre convidado e anfitrião.

A ausência de ineditismo também é um problema, pois oferecer os assuntos de sempre pode ser uma estratégia fastidiosa, assim é preciso se atentar (não apenas ao financiamento do aparato tecnológico), mas também para a possibilidade do comunicar com qualidade de estruturação temática, divulgado de maneira que corresponda às necessidades da plateia, gerando uma relaçao saudável para com os interessados, ponderando aquilo que é favorável para a situação [9], protegendo assim a saúde mental de quem ouve, mas também precisa ser ouvido. Logo, dando a devida atenção aos feedbacks (que por vezes costumam ser relegados pelos conferencistas) e apropriar-se deles será possível melhorar ações posteriores e cumprir a meta - preservar a saúde mental por meio do reforço da espiritualidade em tempos das pandemias ainda ininteligíveis, o COVID-19 e as live's desarmonizadas.

\section{CONSIDERAÇÕES FINAIS}

Enquanto percebe-se um esforço sistemático para manter igrejas e templos abertos, os espíritas não se 
desalinham dos seus tripés - religião, filosofia e and target populations. Psychiatry Clin Neurosciences. ciência - entendendo claramente que o saber científico é 2020, v.74(4): 281-282. doi: 10.1111/pcn.12988 o recomendável, incentivando a frase mais proferida na atualidade: "se possivel fique em casa". O que demonstra o uso coerente da raz do poder divino frente a uma pandemia que atinge não função do isolamica, mas tambem a saúde mental em função do isolamento ou distanciamento social e do medo em todas as suas dimensões.

As live's que envolvem espiritualidade são combustíveis para enfrentamento das fragilidades emocionais do momento global, porém precisam ser otimizadas para que não sejam "mais do mesmo". As pautas necessitam da diversidade (sem menosprezar a capacidade intelectiva dos próprios seguidos que evidenciam argúcia e bom senso), os horários carecem de alternativas (apesar da disponibilidade dos vídeos para acesso a qualquer tempo, contudo isso inviabiliza a inter-relação) e requerem atenção especial ao espectador. Assim, servirão de verdadeira fonte de cuidado para com as dimensões humanas, indo além de um meio de manter a visibilidade ou demonstrar a perspicácia do provedor (quando este a detém).

Do outro lado da tela há um auditor passivo que poderia se valer do recurso cibernético ultrapassando os limites do papel de coadjuvante para que essas investidas não sejam vistas como um mero entretenimento ou alternativa tolhida de interatividade. Que as "curtidas" e os comentários não sejam interpretados apenas como uma forma de marcar presença, pois as pessoas também precisam ser vistas e atendidas em suas demandas. Assim, aquele que se dispõe a contribuir para o bemestar espiritual, que refletirá na saúde mental de seus espectadores, será verdadeiramente cooperativo e não continuará "enxugando gelo"

\section{AGRADECIMENTOS}

Nadine Cilene Rodrigues Gonçalves

Orlando Noronha Carneiro

\section{REFERÊNCIAS}

1. Freire P. Pedagogia da autonomia: saberes necessário à prática educativa. São Paulo: Paz e Terra, 2009

2. Shigemura J, et al. Public responses to the novel 2019 coronavirus (2019-nCoV) in Japan: mental health
3. Serrano RMSM. Conceitos de extensão universitária: um diálogo com Paulo Freire Disponível em: https://crystine-tanajura.webnode. com/_files/200000021-e6560e752b/conceitos_de_ extensao_universitaria.pdf. Acesso em: mai 2020.

4. Oliveira MR, Junges JR. Saúde mental e espiritualidade/ religiosidade: a visão de psicólogos. Estudos de Psicologia. 2012, v17(3): 469-476. Disponivel em: https://mwwiedalc.

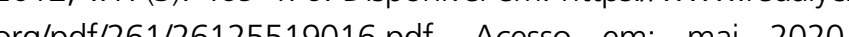
5. Gibson JL, Ivanesch JM, Donnelly JH. Organizações: comportamento, estrutura, processos. São Paulo: Atlas, 2012. 6. Paulon SM, Carnero MLF. A educação a distância como dispositivo de fomento às redes de cuidado em saúde. Interface (Botucatu). 2009, v.13(1): 749-757. Disponível em:< http:// www.scielo.br/scielo.php?script=sci_arttext\&pid=\$141432832009000500026\&lng=en>. https://doi.org/10.1590/ \$1414-32832009000500026. Acesso em: mai 2020. 7. Santos MS, Costa CA, Barbosa JLV. Uma Proposta de Rede Social Espontânea para Interação Ubiqua em Eventos. In: Anais do VIII Simpósio Brasileiro de Computação Ubíqua e Penvasiva, 2020, p. 300-309. Porto Alegre: SBC. doi:10.5753/sbcup. 2016.9471. 8. Duarte F, Frei, K. Redes Urbanas. O Tempo Das Redes, Rio de Janeiro. 2016, v. 1, p. 22-32. Disponível em: < https://www.

9. Oliveira GL. Comunicação e espiritismo: uma análise da Associação Espírita José Ferreira de Moraes através do facebook 2017, P. 51. Trabalho de Conclusão do Curso (Graduação

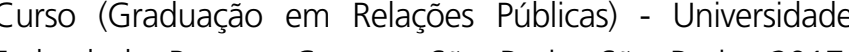
Públicas. São Paulo: Pioneira Thomson Learning, 2006.

11. Ferreira JCF. A imagem na web: fotojornalismo e internet. In: XXVI Congresso Brasileiro de Ciências da Comunicação 2003, Belo Horizonte. Anais eletrônicos. Belo Horizonte: Intercom, 2003. Disponível em: <http:// www.intercom.org.br/papers/nacionais/2003/www/ maxwell.vrac.puc-rio.br/28124/28124>. Acessoem:mai2020. 10. Kunsh MMK. Obtendo Resultados com Relações
pdf/2003_NP02_ferreira.pdf>. Acesso em: mai. 2020. 12. Vergili R. Relações Públicas, mercado redes sociais 1a ed São Paulo: Summus; 2014

13. Xavier FC, Vieira, W. In: Estude e Viva. Pelos Espíritos Emmanuel/André Luiz. FEB: Rio de Janeiro, 1965 